\title{
Productivity estimation in Halodule wrightii: comparison of leaf-clipping and leaf-marking techniques, and the importance of clip height
}

\author{
Joseph L. Kowalski ${ }^{1}$, Hudson R. DeYoe ${ }^{1, *}$, Terry C. Allison ${ }^{1}$, James E. Kaldy ${ }^{2}$ \\ ${ }^{1}$ Department of Biology, The University of Texas - Pan American, 1201 West University Dr., Edinburg, Texas 78539, USA \\ ${ }^{2}$ Texas A\&M University, Oceanography Department, College Station, Texas 77843, USA
}

\begin{abstract}
We compared estimates of Halodule wrightii leaf growth rates obtained from leaf-clipping and leaf-piercing methods in a south Texas lagoon. Leaf clipping underestimated leaf production from 15 to $37 \%$ in winter and 25 to $60 \%$ in summer relative to leaf piercing. The underestimation of leaf-clipping derived growth rates were corrected using a linear regression between leaf growth rates determined by leaf-clipping and leaf-piercing methods. To examine the effect of clip height on $H$. wrightii leaf growth rate estimation, leaves were clipped at $0,2,4,6$, and $8 \mathrm{~cm}$ above the sediment. Leaves clipped at $2 \mathrm{~cm}$ exhibited the fastest leaf growth rate (average $=3.66 \mathrm{~mm} \mathrm{~d}^{-1}$ ) while leaves clipped at $8 \mathrm{~cm}$ had the slowest rate (average $=2.30 \mathrm{~mm} \mathrm{~d}^{-1}$ ). Depressed leaf growth rates for $8 \mathrm{~cm}$ clip height were likely due to the slowing of growth rate with increasing leaf age. Reduced growth rate for the $0 \mathrm{~cm}$ clip height treatment may be attributable to removal of nearly all photosynthetic tissue and limited below-ground resources. In design of leaf-clipping studies, it is suggested that the selection of clip height and the period of growth after clipping be optimized for each season of a study.
\end{abstract}

KEY WORDS: Leaf clipping · Leaf piercing $\cdot$ Productivity techniques $\cdot$ Halodule wrightii · Texas · Seagrass

\section{INTRODUCTION}

Halodule wrightii (shoal grass) is a narrow-leaved seagrass found in bays and estuaries across the Gulf of Mexico (Dawes 1987). It is the most abundant seagrass in Texas coastal waters (Adair et al. 1994), where it is a key ecological species (Onuf 1994). A widely used method for measuring leaf production in broad-leaved seagrasses, such as Thalassia testudinum and Zostera marina, involves piercing the leaves in the bundle sheath, just above the basal meristem (a variation of the Zieman 1974 method, Sand-Jensen 1975). The leaves of $H$. wrightii are generally $1 \mathrm{~mm}$ or less in width (Phillips \& Meñez 1988 pers. obs.) and shoot

*E-mail: hdeyoe@panam.edu densities commonly exceed $5000 \mathrm{~m}^{-2}$ in subtidal populations in Laguna Madre, Texas (Kowalski 1999); thus, piercing the bundle sheath of $H$. wrightii is difficult. Few studies have used leaf piercing for productivity estimation of $H$. wrightii (Powell et al. 1989). Virnstein (1982) devised an in situ method for measuring $H$. wrightii leaf growth, which involved clipping the plants 1 to $2 \mathrm{~cm}$ above the sediment and subsequently photographing their growth. This method requires special equipment, relatively clear water, and low to moderate shoot densities. Dunton (1990) modified the protocol of Virnstein (1982) to that of a 'clip and harvest' approach (leaf clipping). This technique is simple and inexpensive, and circumvents the problems associated with thin leaves and high shoot densities, but it underestimates productivity by at least $50 \%$, presumably because photosynthetic tissue is removed and clipped leaves are wounded (Tomasko \& Dunton 
1995). In their study, Tomasko \& Dunton (1995) used only 1 clip height ( $1 \mathrm{~cm}$ above basal sheath) and did not compare the leaf-marking with the leaf-clipping technique. We speculated that clipping at different heights would produce different leaf elongation rates as a function of the amount of photosynthetic tissue removed and the age of the leaf.

Although Tomasko \& Dunton (1995) found that leaf clipping underestimated production, they concluded that leaf turnover and biomass calculations were appropriate for obtaining accurate production estimates. The need for leaf turnover rates requires estimates of leaf growth rates, and it is this parameter that has proved difficult to assess accurately in Halodule wrightii.

Other methods used to assess productivity in Halodule wrightii include carbon isotope uptake and oxygen evolution (Morgan \& Kitting 1984, Dunton \& Tomasko 1994). More recently, pulse amplitude modulated fluorometry has been used with $H$. wrightii to measure the effective quantum yield of photosystem II (Beer \& Bjork 2000). These methods are considerably more complex and costly than leaf clipping.

When using leaf-clipping or leaf-piercing techniques to estimate seagrass production, it is useful to understand the leaf growth or elongation pattern for the species of interest and factors influencing leaf growth rate. Virnstein (1982) found that leaves of Halodule wrightii initially follow a logistic growth curve, undergo a period of declining growth rate, stop growth, achieve terminal leaf length, and then senesce, as is true of other seagrass species (e.g. Halodule uninervis, Brouns 1987, Syringodium filiforme, Fry 1983, T. testudinum, van Tussenbroek 1995). Studies by Greenway (1974), Virnstein (1982), Wittmann \& Ott (1982), Tomasko \& Dawes (1989), and Cebrian et al. (1998) have examined the effect of clipping on seagrass leaf growth. Removal of most of the leaf tissue of a shoot causes the subtending rhizome reserves and possibly those of the neighboring shoots and rhizomes to be used (Tomasko \& Dawes 1989). Seagrass species that have small rhizomes, such as $H$. wrightii, have little reserve carbon and would be expected to have reduced shoot growth rates, or leaves would fail to achieve average terminal length, if a large proportion of leaf area is removed.

In terrestrial plants, differences in leaf growth rates resulting from different clip heights have long been observed in grasses (Albertson et al. 1953, Cook et al. 1958). More recently, Moreno et al. (1999) and Paige (1999) found that terrestrial grass shoots clipped closer to the meristem had slower leaf growth rates than those clipped at higher levels (McNaughton et al. 1983). The effect of clipping on final leaf biomass varies in terrestrial plants, with undercompensation (Sharma et al. 1998), exact compensation (Raillard \& Svaboda 1999), and overcompensation (Moreno et al.
1999, Paige 1999) having been observed. Explanations for varying results have been attributed to life history differences (Sharma et al. 1998, for wetland annual compared with perennial), sediment and plant nutrient status (Raillard \& Svaboda 1999, for an arctic sedge; Moreno et al. 1999 for Amaranthus sp.) and sexual reproduction differences (Mulder \& Ruess 1998, for arrow grass).

To investigate the above issues, we clipped Halodule wrightii shoots at $0,2,4,6$, and $8 \mathrm{~cm}$ above the sediment to determine which clip height results in the highest leaf growth rate. In addition, we compared $H$. wrightii leaf elongation rates based on leaf-piercing and leaf-clipping methods to determine which method produces the highest leaf growth rates.

\section{MATERIALS AND METHODS}

Study site. The studies were conducted in Lower Laguna Madre, Texas, approximately $10 \mathrm{~km}$ north of Brazos-Santiago Pass in a monotypic stand of Halodule wrightii, approximately $500 \mathrm{~m}$ west of the Gulf Intracoastal Waterway (26 9.0952' N, 97 $14.432^{\prime}$ W) (Fig. 1). Sediment at the study site is dredged material and is approximately $15 \mathrm{yr}$ old. Sediment grain size distribution was $9 \%$ shell rubble (grain size $>0$ phi, Folk 1964), $62 \%$ sand, $13 \%$ silt, and $16 \%$ clay (Kowalski 1999). Astronomical tides seldom exceed $20 \mathrm{~cm}$ in Laguna Madre (Hedgepeth 1947). Wind velocities are generally 6 to $12 \mathrm{~m} \mathrm{~s}^{-1}$ for most of the year (Brown \& Kraus 1997) and with an $8 \mathrm{~km}$ fetch from the southeast that during the study occasionally produced high waves and caused water levels to fluctuate between 0.9 and $1.3 \mathrm{~m}$ (average $=1.2 \mathrm{~m}$ ) at the study site. During the study, surface water temperatures varied seasonally ranging between 8 and $31^{\circ} \mathrm{C}$ while surface salinity varied between 24 and $40 \%$.

Experimental design. Leaf-clipping versus leafpiercing experiment: In 9 experiments performed between July 1995 and January 1997, leaf growth rates based on leaf-clipping and leaf-piercing techniques were compared. Experiments were conducted in dense $\left(>5000\right.$ shoots $\mathrm{m}^{-2}$ ) and uniform stands of Halodule wrightii. For each experiment, shoots were clipped $2 \mathrm{~cm}$ above the sediment in one $50 \times 50 \mathrm{~cm}$ quadrat (no replicate quadrats). Leaves were clipped with garden shears with clip height measured using a $50 \times 50 \mathrm{~cm}$ $\left(0.25 \mathrm{~m}^{2}\right)$ adjustable PVC pipe and wire frame. Just after clipping, 1 core was taken in each quadrat near the periphery for determination of average clip height. Post-clip growth periods varied between 7 and $14 \mathrm{~d}$. After the growth period, 4 cores were harvested from the middle of each quadrat to reduce the likelihood of edge effects. Also at the end of the growth period, 4 


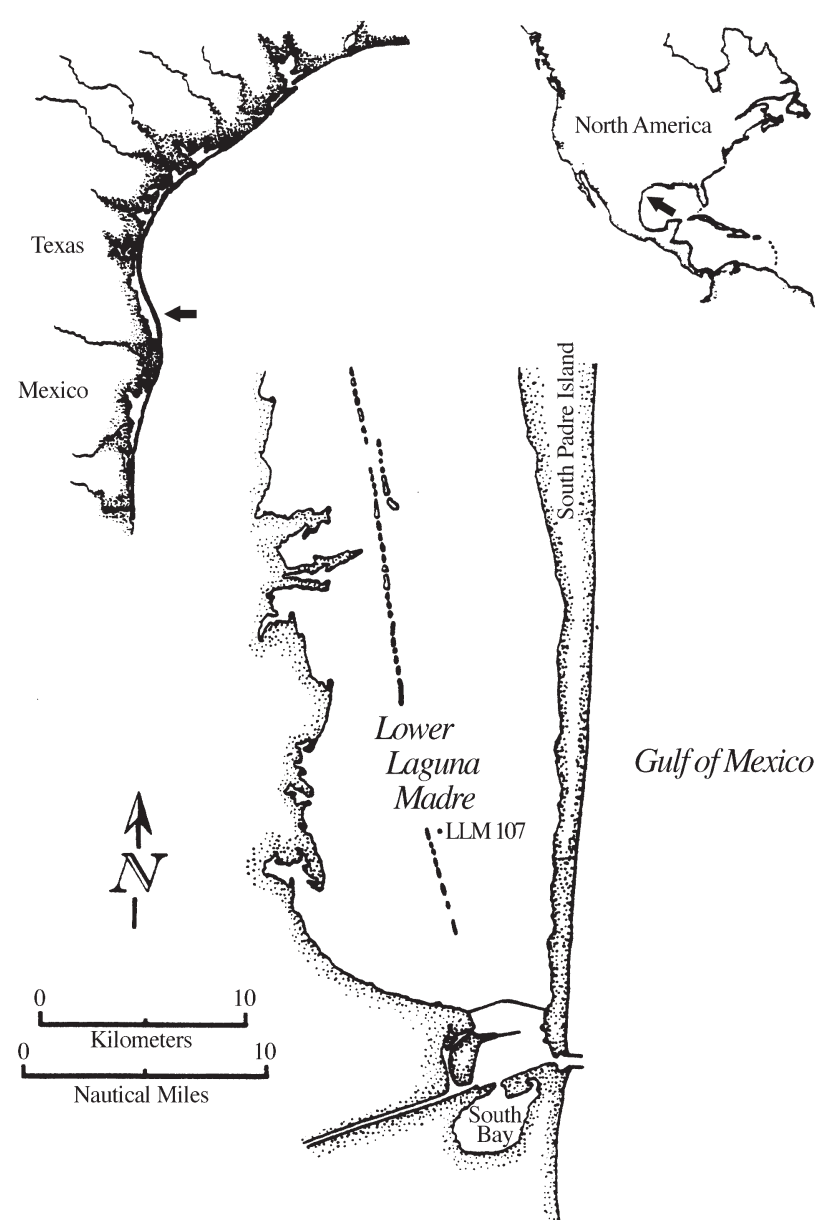

Fig. 1. Map of the study area and location of study site (LLM 107) in lower Laguna Madre, Texas

unclipped cores were taken outside the clipped areas about $2 \mathrm{~m}$ from the quadrats for estimation of average terminal leaf length. The 5 cores $(9 \mathrm{~cm}$ diameter, $0.006 \mathrm{~m}^{2}$ core $^{-1}, 15 \mathrm{~cm}$ in depth) taken from each quadrat sampled approximately $13 \%$ of a quadrat. For the leaf-piercing technique, the bundle sheaths of 20 to 30 shoots were pierced just above the basal meristem with a 28 gauge hypodermic needle $(<0.5 \mathrm{~mm}$ diameter). Piercing was done coincident with clipping at least $2 \mathrm{~m}$ from clipped quadrats. The base of each pierced shoot was tagged with a ring of tubing to facilitate relocation of marked shoots. On the same day as clipped plots were harvested, pierced shoots were harvested by severing shoots at rhizome level, sealing them in plastic bags, and refrigerating them until analysis. In the laboratory, the needle mark on the oldest leaf sheath was located and the shoot was cut at that location. Leaves from the shoot were separated by age and the distance between the cut surface and the needle mark, or in the absence of a mark, the leaf tip was measured $(\mathrm{mm})$. Leaf growth rates expressed as $\mathrm{mm} \mathrm{d}^{-1}$ were calculated by dividing the average leaf growth interval by the number of days of growth.

For these experiments, mean leaf growth rates of the 2 techniques were compared using an independent samples $t$-test. In the $t$-test, the 9 different experiments were treated as replicates. A generalised linear model procedure (Sigma Plot 4.0 for Windows, SPSS Inc, Chicago, IL) was used for regression analysis using a least-squares fit between average growth rates determined by leaf-clipping and leaf-marking methods. An alpha level of 0.05 was used for statistical tests.

Variable clip height experiment: Five clip height experiments were performed between June and July 1995. There were 5 clip height treatments, i.e. seagrasses were clipped $0,2,4,6$, and $8 \mathrm{~cm}$ above the sediment, in separate quadrats at least $2 \mathrm{~m}$ apart. In each experiment, clip treatments were not replicated but new quadrats were established for each experiment.

Leaves were clipped using garden shears with clip heights measured using a $50 \times 50 \mathrm{~cm}\left(0.25 \mathrm{~m}^{2}\right)$ adjustable PVC pipe and wire frame. Just after clipping, 1 core was taken in each quadrat near the periphery for determination of average clip height. Post-clip growth periods varied between 7 and $14 \mathrm{~d}$. After the growth period, 4 cores were harvested from the middle of each quadrat. Also at the end of the growth period, 4 unclipped cores were taken from outside the clipped areas about $2 \mathrm{~m}$ from the quadrats for estimation of average terminal leaf length.

All cores were gently cleaned of sediment and the plant material was sealed in plastic bags and refrigerated until processed. In the laboratory, leaves were separated from the shoots and leaf lengths were measured from the leaf tip to where the leaf changed from green (photosynthetic tissue) to white (non-photosynthetic tissue). All leaves of a shoot were measured and 10 to 20 leaves were measured to the nearest mm from each core. Leaves less than the clip height were not included in the data set. The initial average clip height was subtracted from the average final leaf length of clipped shoots of each treatment and divided by the growth period to obtain leaf growth rate in $\mathrm{mm} \mathrm{d}^{-1}$.

The variable clip height experiment was repeated 5 times over a 2 mo period. Each experiment used the same clip height treatments. For statistical analysis, the 5 experiments were considered blocks in a 1-way ANOVA with the dependent variable being leaf growth rate and the independent variable being leaf clip height. The sampling unit was the leaves of a shoot. When differences in means were found, Tukey's multiple comparison test was used to detect which clip treatments were different. Post-hoc testing determined that the data were normally distributed. An alpha level of 0.05 was used for statistical tests. 


\section{RESULTS AND DISCUSSION}

\section{Leaf-clipping versus leaf-piercing experiment}

Pierced leaves were clearly discernible as complete holes (scars) or nicked edges. In general, the holes created by piercing were approximately half the width of the blade, but piercing generally did not damage leaves to the point that leaf tissue above the scar died. All leaf portions, whether clipped or pierced, appeared as green as control leaves. The mean growth rate for pierced leaves during June and July 1995 was $6.8 \mathrm{~mm} \mathrm{~d}^{-1}$ and was 2 to 3 times the rate of the $2 \mathrm{~cm}$ clipped plants ( $p<0.001$, Fig. 2). Clipping underestimated leaf growth by more than $60 \%$ during the peak growth season in late spring to early summer, and by $15 \%$ in winter (December to February). Estimates of leaf growth rates for clipped and pierced plants were consistently different and well correlated over the 20 mo study period $\left(p=0.0018, r^{2}=0.77\right)$. The relation is described by $y=2.18 x-0.34$, where $y$ is clip method growth rate and $x$ is the pierce method growth rate (Fig. 3).

Although leaf piercing damages the leaf, piercing appears to be less damaging than clipping as the leafpiercing technique consistently gives higher leaf growth rates in Halodule wrightii than the leaf-clipping method. The linear relation between leaf growth rates of clipped and of pierced plants can be used to correct for underestimation inherent in the leafclipping technique. Because of site-specific differences

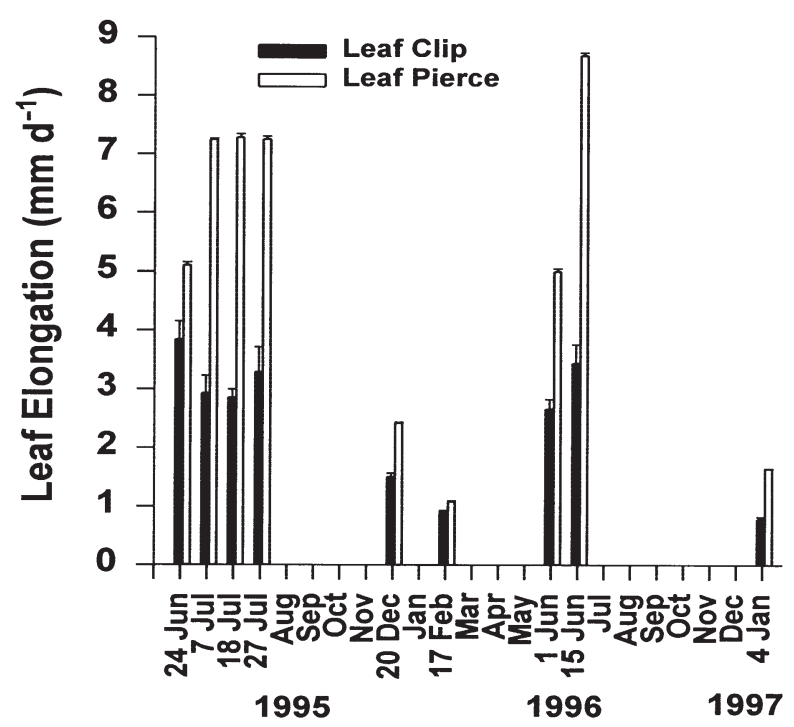

Fig. 2. Mean leaf growth rates $\left(\mathrm{mm} \mathrm{d}^{-1}\right)$ of Halodule wrightii clipped at $2 \mathrm{~cm}$ (black bars) above the sediment surface and pierced leaves (white bars) for June 1995 to January 1997 experiments. Where no error bar appears, SE is smaller than data point marker

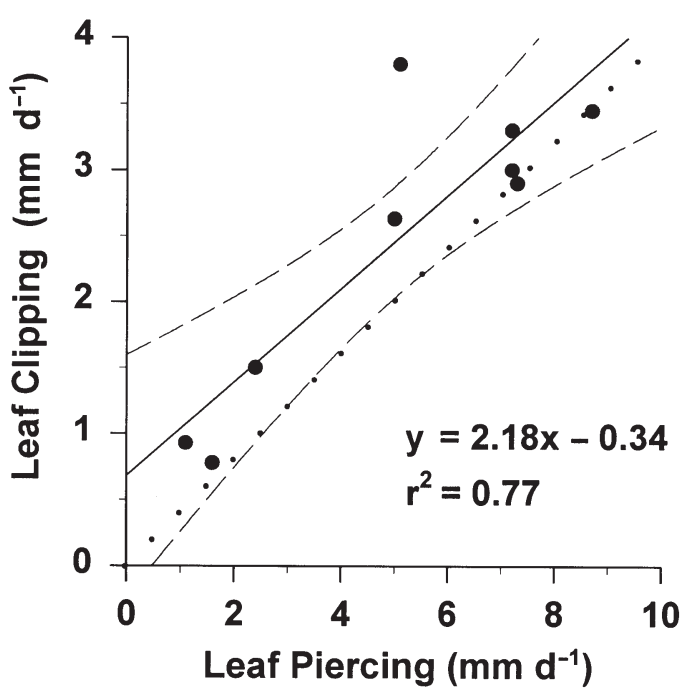

Fig. 3. Regression analysis of the relation between leaf growth rates determined by leaf-piercing and leaf-clipping methods for Halodule wrightii over a 20 mo period. $95 \%$ CIs indicated by dashed lines. The dotted line is the 1:1 line

that commonly exist among natural seagrass populations (Dunton 1996), our quantitative relation is likely not appropriate for $H$. wrightii populations outside the Lower Laguna Madre or at depths and shoot densities not encountered in this study. We recommend that investigators develop a regression equation appropriate for their particular region and use this relation with appropriate caution.

Adequate water transparency is necessary to pierce leaves little more than $1 \mathrm{~mm}$ wide. When water transparency is poor, the leaf-clipping technique is invaluable because leaves can be clipped almost entirely by feel. Exclusive use of the leaf-clipping technique regardless of clip height (see below) would significantly underestimate leaf elongation rates. The leafclipping method is appropriate for site or treatment comparison studies without correction and for determining leaf production in Halodule wrightii when used with a correction based on the leaf-piercing technique.

\section{Variable clip height experiment}

Mean leaf growth rate was greatest for the $2 \mathrm{~cm}$ clip height $\left(3.66 \mathrm{~mm} \mathrm{~d}^{-1}\right)$ and least for the $8 \mathrm{~cm}$ treatment $\left(2.30 \mathrm{~mm} \mathrm{~d}^{-1}\right)$ (Table 1$)$. The rates for the 0,4 , and $6 \mathrm{~cm}$ clip heights were intermediate and varied between 3.35 (0 cm treatment) and 3.45 (6 cm treatment) $\mathrm{mm} \mathrm{d}^{-1}$. ANOVA determined that there were significant differences in mean leaf growth rates among the clip treatments $(p=0.005)$. According to Tukey's multiple comparison test, there were no significant differences among the $0,2,4$, and $6 \mathrm{~cm}$ treatments while each dif- 
Table 1. Variable clip height experiment: results of Tukey's multiple comparison test based on Halodule wrightii mean leaf growth rates $\left(\mathrm{mm} \mathrm{d}^{-1}\right)$. Values with the same letter are not significantly different

\begin{tabular}{|cccc|}
\hline Clip height $(\mathrm{cm})$ & Mean \pm SE & Tukey \\
\hline 2 & $3.66 \pm 0.30$ & A & \\
4 & $3.55 \pm 0.30$ & A & \\
6 & $3.45 \pm 0.27$ & A & B \\
0 & $3.35 \pm 0.41$ & A & B \\
8 & $2.30 \pm 0.35$ & & B \\
\hline
\end{tabular}

fered from the $8 \mathrm{~cm}$ treatment, and in the secondary comparison the 0,6 , and $8 \mathrm{~cm}$ treatments differed from the 2 and $4 \mathrm{~cm}$ treatments (Table 1).

On the basis of the primary Tukey comparison, the 0 to $6 \mathrm{~cm}$ clip height leaf growth rates did not differ, while all differed from the $8 \mathrm{~cm}$ treatment. These results contradict our original hypothesis that the higher the proportion of leaf tissue removed the slower the leaf growth rate. On the basis of our results, it appears that the plants had adequate stored resources (from subtending rhizomes or neighboring ramets) or enough production from the remaining photosynthetic tissue to maintain the same growth rate regardless of the amount of leaf material removed. The low mean growth rate for the $8 \mathrm{~cm}$ clip was due to the clipped leaves being relatively old. It is presumed that their rate of elongation slowed with increasing age as seen in Zostera marina (Jacobs 1979) and Thalassia testudinum (Patriquin 1973, van Tussenbroek 1995). The secondary Tukey comparison indicated no difference among the 0,6 , and $8 \mathrm{~cm}$ clip treatments, which differed from the 2 and $4 \mathrm{~cm}$ treatments. The low rate for the $0 \mathrm{~cm}$ clip suggests that there was a negative effect on growth rate of removing nearly all the photosynthetic tissue from a shoot. The depressed rate for the $6 \mathrm{~cm}$ clip suggests that leaves able to be clipped at $6 \mathrm{~cm}$ may be old enough to show depressed growth rates as with $8 \mathrm{~cm}$ clipped leaves.

In our study, clipping effects on Halodule wrightii leaves showed exact compensation of biomass in contrast to undercompensation reported by Morgan \& Kitting (1984) for the same species. As with other seagrasses, the roots and rhizomes of $H$. wrightii act as a soluble carbohydrate reservoir for growth, having lowest reserves in spring and highest in the fall (Dawes \& Lawrence 1980, Kowalski 1999). Morgan \& Kitting (1984) did not explain their findings. Complete biomass compensation in cropped shoots has been shown for other tropical and subtropical seagrass species (Cebrian et al. 1998).

Our results indicate that the selection of clip height in a leaf-clipping study can affect the degree of under- estimation of leaf growth rate values. Besides the obvious effect of very long clip heights, underestimation would likely be amplified when lower clip heights are used where the plants have low resource reserves during springtime, when plants are under environmental stress or when shoot density is low. Under these conditions, actual growth rates (determined by leaf piercing) and leaf clip-determined growth rates may increasingly differ the greater the proportion of each leaf removed and the more leaves that are removed. The more photosynthetic material removed the greater the draw on plant reserves (immediate or distant). When reserves become limiting, growth would become more a function of leaf photosynthetic production rate, resulting in slower leaf growth rates or failure of leaves to achieve the pre-clip terminal height (Morgan \& Kitting 1984). It is partly for this reason that the same plots should not clipped repeatedly to measure leaf growth rates in seagrass research.

There is perhaps another reason to avoid the use of short clip heights. In Thalassia testudinum, Patriquin (1973) found that a small amount of leaf elongation occurred at leaf marks $5 \mathrm{~cm}$ above the sediment. This effect would likely have been more pronounced if marks lower than $5 \mathrm{~cm}$ had been used. If post-meristematic region growth occurs with Halodule wrightii, it would be of interest to determine how much this type of growth contributes to total leaf growth.

Besides clip height, the choice of the length of the growth period between clipping or piercing and harvest should be evaluated when measuring leaf growth rates. During warmer months, Halodule wrightii leaf growth rates and terminal leaf lengths are greater (Kowalski 1999) and likely plastochrone intervals (Erickson \& Michellini 1957) shorter than during colder months. The majority of leaves clipped or pierced on a shoot should be harvested before their growth rate starts to slow with age, i.e. before they near their terminal length. On the other hand, the growth period needs to be long enough to achieve an increment of growth that would show significant differences from the initial clip height. Because of these factors, it is suggested that preliminary measurements be performed during each season of a study to determine appropriate intervals between clipping or piercing and harvest.

Acknowledgements. We thank J. White and C. Krull for help in the field, and Ms. L. H. Hirsch for valuable lab assistance. We also thank D. Hockaday for his assistance and the use of the University of Texas-Pan American Coastal Studies Lab. We thank K. Dunton for posing the problem and for improving the manuscript, S. Herzka for discussions and ideas on the details of the research, and F. Judd for help with the statistical analysis. We gratefully acknowledge D. Flemer, K. Lee, K. Major, and C. Onuf for providing excellent comments on early versions of the manuscript and 3 anonymous reviewers for improving the final version. This research was funded by 
The Texas Higher Education Coordinating Board (Advanced Research Program Grant \#003658-419), a grant from The University of Texas-Pan American Faculty Research Council, and The University of Texas-Pan American James-Ware-Foltz Scholarship fund.

\section{LITERATURE CITED}

Adair SE, Moore JL, Onuf CP (1994) Distribution and status of submerged vegetation in estuaries of the upper Texas coast. Wetlands 14:110-121

Albertson FW, Riegel A, Launchbaugh JL Jr. (1953) Effects of different intensities of clipping on short grasses in westcentral Kansas. Ecology 34:1-20

Beer S, Björk M (2000) Measuring rates of photosynthesis of two tropical seagrasses by pulse amplitude modulated (PAM) fluorometry. Aquat Bot 66:69-76

Brouns JJWM (1987) Aspects of production and biomass of four seagrass species (Cymodoceoideae) from Papua New Guinea. Aquat Bot 27:333-362

Brown CA, Kraus NC (1997) Environmental monitoring of dredging and processes in Lower Laguna Madre, Texas. Conrad Blucker Institute Technical Report TAMU-CCCBI-96-01. Conrad Blucker Institute, Corpus Christi, TX

Cebrián J, Duarte CM, Agawin NSR, Merino M (1998) Leaf growth response to simulated herbivory: a comparison among seagrass species. J Exp Mar Biol Ecol 220:67-81

Cook CW, Stoddart LA, Kinsinger FE (1958) Responses of crested wheatgrass to various clipping treatments. Ecol Monogr 28:237-272

Dawes CJ (1987) The dynamic seagrasses of the Gulf of Mexico and Florida coasts. In: Durako MJ, Phillips RC, Lewis RR III (eds) Proceedings of the symposium on subtropicaltropical seagrasses of the southeastern United States. Florida Marine Research Publications. Number 42. Florida Department of Natural Resources Bureau of Marine, Research, St. Petersburg, FL, p 25-38

Dawes CJ, Lawrence JM (1980) Seasonal changes in the proximate constituents of the seagrasses Thalassia testudinum, Halodule wrightii, and Syringodium filiforme. Aquat Bot 8:371-380

Dunton KH (1990) Production ecology of Ruppia maritima L. s.l. and Halodule wrightii Aschers. in two subtropical estuaries. J Exp Mar Biol Ecol 143:147-164

Dunton KH (1996) Photosynthetic production and biomass of the subtropical seagrass Halodule wrightii along an estuarine gradient. Estuaries 19:436-447

Dunton KH, Tomasko DA (1994) In situ photosynthesis in the seagrass Halodule wrightii in a hypersaline subtropical lagoon. Mar Ecol Prog Ser 107:281-293

Erickson RO, Michellini FJ (1957) The plastochrone index. Am J Bot 44:297-305

Folk RL (1964) Petrology of sedimentary rocks. Hemphill Publishing Co., Austin

Fonseca MS, Kennworthy WJ, Courtney FX (1996) Development of planted seagrass beds in Tampa Bay, Florida, U.S.A. II. Plant components. Mar Ecol Prog Ser 132:127-139

Fry B (1983) Leaf growth in the seagrass Syringodium filiforme Kütz. Aquat Bot 16:361-368

Greenway M (1974) The effects of cropping on the growth of the Thalassia testudinum (König) in Jamaica. Aquaculture 4:199-206

Hedgepeth J (1947) The Laguna Madre of Texas. In: Quee EM (ed) Transactions of the 12th North American Wildlife Conference, Wildlife Management Institute, Washington, DC, p 364-380
Jacobs RPWM (1979) Distribution and aspects of the production and biomass of eelgrass, Zostera marina L., at Roscoff, France. Aquat Bot 7:151-172

Kowalski JL (1999) Production of the subtropical seagrass, Halodule wrightii Aschers., in Lower Laguna Madre, Texas. MSc thesis, University of Texas - Pan American

McNaughton SJ, Wallace LL, Coughenour MB (1983) Plant adaptation in an ecosystem context: effects of defoliation, nitrogen, and water on growth of an African $\mathrm{C}_{4}$ sedge. Ecology 64:307-318

Moreno DM, Núñez-Farfán J, Terrazas T, del Mar Ruiz P. L, Trinidad-Santos, Trejo LC, Larque-Saavedra A (1999) Plastic responses to clipping in two species of Amaranthus from the Sierra de Puebla, Mexico. Genet Resour Crop Evol 46:225-234

Morgan MD, Kitting CL (1984) Productivity and utilization of the seagrass Halodule wrightii and its attached epiphytes. Limnol Oceanog 29:1066-1076

Mulder CPH, Ruess RW (1998) Relationships between size, biomass allocation, reproduction, and survival in Triglochin palustris: implications for the effects of goose herbivory. Can J Bot 76:2164-2176

Onuf CP (1994) Seagrass meadows of lagoonal systems of coastal Texas. National status trends report. US National Biological Survey, Corpus Christi, TX

Paige KN (1999) Re-growth following ungulate herbivory in Ipomopsis aggregata: geographic evidence for overcompensation. Oecologia 118:316-323

Patriquin D (1973) Estimation of growth rate, production and age of the marine angiosperm Thalassia testudinum Konig. Caribb J Sci 13:111-123

Phillips RC, Meñez EG (1988) Seagrasses. Smithson Contrib Mar Sci 34, Smithsonian Institute, Washington, DC, p 52

Powell GVN, Kenworthy WJ, Fourqurean JW (1989) Experimental evidence for nutrient limitation of seagrass growth in a tropical estuary with restricted circulation. Bull Mar Sci 44:324-340

Raillard MC, Svaboda J (1999) Exact growth and increased nitrogen compensation by the Arctic sedge Carex aquatilis var. stans after simulated grazing. Arct Antarct Alp Res 31:21-26

Sand-Jensen K (1975) Biomass, net production and growth dynamics in an eelgrass (Zostera marina L.) population in Vellerup Vig, Denmark. Freshwat Biol Lab 14:185-201

Sharma, KP, Kushwaha SPS, Gopal B (1998) A comparative study of stand structure and standing crops of two wetland species, Arundo donax and Phragmites karka, and primary production in Arundo donax with observations on the effect of clipping. Trop Ecol 39:3-14

Tomasko DA, Dawes CJ (1989) Effects of partial defoliation on remaining intact leaves in the seagrass Thalassia testudinum Banks ex König. Bot Mar 32:235-240

Tomasko DA, Dunton KH (1995) Primary productivity in Halodule wrightii: a comparison of techniques based on daily carbon budgets. Estuaries 18:271-278

van Tussenbroek BI (1995) Thalassia testudinum leaf dynamics in a Mexican Caribbean coral reef lagoon. Mar Biol 122:33-40

Virnstein RW (1982) Leaf growth of the seagrass Halodule wrightii photographically measured in situ. Aquat Bot 12: 209-218

Wittmann KJ, Ott JA (1982) Effects of cropping on the Mediterranean seagrass Posidonia oceanica (L.) Delile. Mar Ecol 3:151-159

Zieman JC (1974) Methods for the study of the growth and production of the turtle grass, Thalassia testudinum König. Aquaculture 4:139-143 